\title{
Syngenta's gaff embarrasses industry and White House
}

Late in March it was widely reported that the Swiss agribusiness group Syngenta had inadvertently mislabeled and sold Bt-10, an unapproved genetically modified (GM) corn seed, as Bt-11, which is approved, to US farmers between 2001 and 2004. Although the US government deemed the matter to be a legal rather than health or environmental matter, this latest industry public relations mishap may strengthen calls to tighten legislation on genetically modified (GM) products in the US. Meanwhile, the incident provided new ammunition for an old gripe over trade between the US and the EU, which launched its own investigation.

After Nature broke the story on March 24, Syngenta disclosed that its Bt-10 test line somehow found its way into five production lines of Bt-11. Bt-10, which like Bt-11 contains a toxin gene from the soil bacterium Bacillus thuringiensis $(B t)$, was kept around purely for research purposes as it did not prosper quite as well in fields as Bt-11. Syngenta says the amount of Bt-10 corn that was sold as Bt-11 would cover an estimated 37,000 acres. For a sense of scale, during that same time 113 million acres of GM corn were planted in the US.

We may never know exactly how or when the comingling occurred, to what extent the global food system was contaminated, or how Syngenta calculated its acreage proclamation. But, all agree that the fact that it did occur suggests that there was some sloppy handling of materials that should have been treated with the utmost of care at all times for any number of reasons-some scientific, others purely political.

Quite predictably, the incident triggered a chain reaction of high-voltage commentary from some European regulators and biotech critics who all but likened the event to the release of a plume of radioactive particles into the atmosphere and chided the company and regulators for putting the public and the environment at risk. "Incidents like the one with Starlink and Syngenta," says Steve Strauss, professor of Forest Science at Oregon State University in Corvalis, "unfortunately strengthen the case for tightening regulations not loosening them at a time when regulations for [biotech versus nonbiotech crops] are already totally out of sync with actual and relative risk factors." (Nat. Biotechnol. 19, 11, 2001).

Although activists have charged that the biotech industry is not to be trusted, Syngenta did, in fact, report this incident immediately upon discovering it in December to the US Department of Agriculture (USDA), the US Food and Drug Administration and the US Environmental Protection Agency (EPA) just as regulations require. US regulators quickly confirmed that Bt-10 posed no human or environmental threat.

Because Bt-10 is not US government approved, planting, selling, distributing, comingling or shipping it without a special government permit is a violation of the Plant Protection Act. Thus far, the USDA has determined that Syngenta was guilty of breaking laws on GM plants and levied a $\$ 375,000$ fine. The EU, on 15 April, announced its intention to require imports of corn-based feed to be certified as free of Bt-10. Meanwhile, the EPA and EU have launched their own investigations, which could result in more fines for the company-and, industry insiders fear, perhaps new regulations for the whole of the GM crop industry.

Syngenta made much of the fact that the Bt-10 corn is identical to Bt-11, which is approved for human consumption in the US, the EU and Japan. In fact, they are similar but not identical. Bt-10 differs from Bt-11 is that it contains an inactive marker gene which originally conferred resistance to ampicillin, a commonly used antibiotic. The inactive gene is a relic from the process used to select transgenic corn cells during strain construction. The release of such genes into the environment has been contested in the past because of the small chance that functional versions could transfer from crops to microorganisms and spread problems of antibiotic resistance. "But for the purposes of the government's investigation," says Jim Rogers a spokesman for the USDA, "this is not a question about exactly how similar or different they are, or about public safety. Both are nearly identical and both are safe. But, only one of them is approved."

Still, Syngenta did themselves, newly installed US Trade Representative Rob Portman and the biotech industry no favorsnot just by letting the Bt-10 seeds slip off radar in the first place, but also by taking nearly 4 months to publicly release information that something was amiss.

Friends of the Earth Europe was prompt to issue a statement saying, "This is an industry out of control ... This [Syngenta] case makes a complete mockery of the US regulatory system for GM crops." Even the relatively mild-mannered Council for Responsible Genetics in Cambridge, Massachusetts, called it a "massive failure of the US regulatory system ... This is certainly going to be a big problem for the United States."

Indeed, the White House has been dragged into this affair because of the potential of Bt-10 to further complicate trade negotiations with Europe. The incident has, however, not alarmed skittish agbiotech investors, who surely would have fled Syngenta shares by now if they believed, as they did with Monsanto shares in 2000 in the wake of a laboratory study on the impact of $B t$ pollen on Monarch butterfly larvae (Nat. Biotechnol. 17, 627, 1999), that political or regulatory trouble was in the offing. In fact, Syngenta's share price, after an initial drop when news broke of the Bt-10 incident, remains close to its 52-week high.

Syngenta is not in the clear yet, however. Regardless of what regulators decide to do about Syngenta's "unintended event," Margaret Mellon of the advocacy group Union of Concerned Scientists says the damage has been done to both the company and the industry. "Environmentalists and the media might have overreacted to this incident," she says. "But it was Syngenta that mishandled things from beginning to end."

Stephan Herrera, New York 